\title{
Comparative Study on Heavy Metals and Hydrocarbons Accumulation in Cassava Tubers Harvested from Four Different Locations in Rivers State, Nigeria
}

\author{
Ndukwe Gloria Ihuoma ${ }^{1}$, Odinga Tamuno-boma ${ }^{2,}$, , Gabriel-Brisibe Christine Umanu ${ }^{3}$, \\ George Damiete Amabinba ${ }^{2}$, Fou Erekedoumene ${ }^{4}$ \\ ${ }^{1}$ Department of Chemistry, Faculty of Science, Rivers State University, Port Harcourt, Nigeria \\ ${ }^{2}$ Department of Biochemistry, Faculty of Science, Rivers State University, Port Harcourt, Nigeria \\ ${ }^{3}$ Department of Biochemistry, College of Medical Sciences, Rivers State University, Port Harcourt, Nigeria \\ ${ }^{4}$ Department of Environmental Management and Control, Institute of Geoscience and Space Technology, Rivers State University, Port \\ Harcourt, Nigeria
}

Email address:

gloria.ndukwe@ust.edu.ng (N. G. Ihuoma), Bomaodinga@gmail.com (O. Tamuno-boma),

Umanubrisibe@gmail.com (Gabriel-Brisibe C. U.), damieteg@gmail.com (G. D. Amabinba),

fouerekedoumene@gmail.com (F. Erekedoumene)

${ }^{*}$ Corresponding author

\section{To cite this article:}

Ndukwe Gloria Ihuoma, Odinga Tamuno-boma, Gabriel-Brisibe Christine Umanu, George Damiete Amabinba, Fou Erekedoumene. Comparative Study on Heavy Metals and Hydrocarbons Accumulation in Cassava Tubers Harvested from Four Different Locations in Rivers State, Nigeria. International Journal of Ecotoxicology and Ecobiology. Vol. 5, No. 2, 2020, pp. 23-28. doi: 10.11648/j.ijee.20200502.12

Received: June 16, 2020; Accepted: June 28, 2020; Published: July 28, 2020

\begin{abstract}
The threat to humans, animals, and plants life by pollution due to gas flare and oil and gas industrial activities cannot be overemphasized. This study compared the hydrocarbons and heavy metals accumulation in cassava tubers harvested from four different locations in Rivers State. The study areas include Rukpoku, Rivers State University (RSU) farm, Eleme community and Nkpolu-Oroworukwo community. Cassava tubers were collected from farms located in the aforementioned areas, prepared and analyzed for hydrocarbons and heavy metals contents. Standard spectro-analytical method was used to determine the concentrations of zinc $(\mathrm{Zn})$, iron $(\mathrm{Fe})$, lead $(\mathrm{Pb})$, copper $(\mathrm{Cu})$ and manganese $(\mathrm{Mn})$, while polycyclic aromatic hydrocarbons (PAHs), total polycyclic hydrocarbon (TPH) and BTEX (benzene, toluene, ethyl benzene, xylene) were analyzed using standard chromatographic procedure. Results obtained from the analyses revealed the presence of heavy metals in all the samples in the order Eleme $>$ Nkpolu-Oroworukwo $>$ Rukpoku $>$ RSU farm. Pb was not detected in the entire sample analyzed, $\mathrm{Mn}$ was below the permissible range, while $\mathrm{Zn}, \mathrm{Fe}$ and $\mathrm{Cu}$ were above the permissible range. TPH was detected in all samples analyzed in the order Eleme > Nkpolu-Oroworukwo > Rukpoku > RSU farm. RSU farm had the least concentration of PAH, While BTEX was not detected in all samples analyzed. The results suggest the presence of heavy metals and hydrocarbons (anthracene, acenaphthene, phenanthrene, fluoranthene, pyrene, benz (a) anthracene, benz (b) fluoranthene, indeno (1,2,3-cd) pyrene, dibenz $(\mathrm{a}, \mathrm{h})$ anthracene) in cassava tubers harvested from the study locations, but with greatest accumulation in samples from Eleme community and least in those from RSU farm. Consumption of such crops could pose health challenges to the consumers over time.
\end{abstract}

Keywords: Hydrocarbon, Heavy Metals, Cassava, Eleme Community, Rivers State University Farm

\section{Introduction}

Cassava (Manihot esculenta Crantz) is the third most important source of calories in the tropics [1] and the sixth most important food crop after sugar cane, maize, rice, wheat and potato, in terms of global annual production [2]. Cassava is a widely accepted plant in Nigeria and a staple food for approximately 800 million people [1]. It serves majorly as food due to its ability to be processed into various products 
such as starch, tapioca, flour, garri, fufu and as food for live stocks. It is the sixth most important food annually produced globally [2].

Oil exploration activities have led to various developments, including economic development in Nigeria, howbeit, the impact of the exploration activities such gas flare, oil spillage and its likes has posed environmental and health risks to humans and animals [3].

Rivers state is located in the Niger delta region of Nigeria and is host to various oil companies. The activities of these oil companies have been a cause of concern to the inhabitants of the state [4]. The consistent black carbon (soot) that is often noticed in the environment as well as oil spillages that affect agricultural land and produce, lead to the deposition of hydrocarbons and heavy metals into the soil.

Nigeria crude oil is known to contain heavy metals such as $\mathrm{Zn}, \mathrm{Al}, \mathrm{Ba}, \mathrm{Fe}, \mathrm{Pb}, \mathrm{Co}, \mathrm{Cu}, \mathrm{Cr}, \mathrm{Mn}, \mathrm{Ni}$ and $\mathrm{V}$ [5]. Heavy metals in the environment are non-degradable and most of them have toxic effect on living organisms when they exceed a certain concentration either in water, soil or food [6]. Excessive accumulation of heavy metals in agricultural soils may result in soil contamination. This causes varying degrees of illness based on acute and chronic exposure [7].

Soil is one of the basic components that support life and productivity in the ecosystem. More so, the flora, fauna and man depend on soil for support and effective functioning. Oil production involves the release of materials and substances that are poisonous and have detrimental impact on the environment [8]. Anthropogenic activities associated with significant production of hydrocarbons include deposition, especially from oil spillage of petroleum and petroleum products. PAHs tend to be more volatile, soluble and relatively mobile in the environment [9].

Aromatic hydrocarbons are considered to be the most acute toxic component of petroleum products, and are also associated with chronic carcinogenic and mutagenic effects [10]. However, various classes of PAHs can differ substantially in their effects on biological systems and behavior in the environment [11]. For example the lower molecular weight compounds, with two or three aromatic rings, such as the naphthalenes, anthracenes and fluoranthenes tend to be the most acutely toxic, whereas the longer PAHs with four to seven rings, such as benzopyrenes, chrysene and coronene, are not acutely toxic but tend to be more carcinogenic. The presence of hydrocarbons in effluents from refining company in Port Harcourt has been reported to alter the metabolic system [12]. This is due to the leaching of the effluent into soils where agriculture crops are planted.

Benzene, toluene, ethyl benzene, and xylene (BTEX) are linked to hormone-related health conditions in humans. Health effects from each chemical individually or in combination include sperm abnormalities, reduced fetal growth, low birth weight, cardiovascular disease, respiratory dysfunction, asthma, sensitization to common antigens and more [13]. Oil spills and oil waste discharged into the sea from refineries, factories or shipping contain poisonous compounds that constitutes potential danger to plants and animals. The poisons can pass through the food web of an area and may eventually be eaten by humans [14].

This study investigated the occurrence and compared the hydrocarbons and heavy metals accumulation in cassava tubers cultivated in four different locations in Rivers state; Eleme community (Eleme local government area) where the Eleme Petrochemical Company and other industries are located, Rukpoku in Obio-Akpor local government area, Rivers State University agricultural farm and NkpoluOroworukwo in Port Harcourt local government area (Figure 1 and Figure 2).

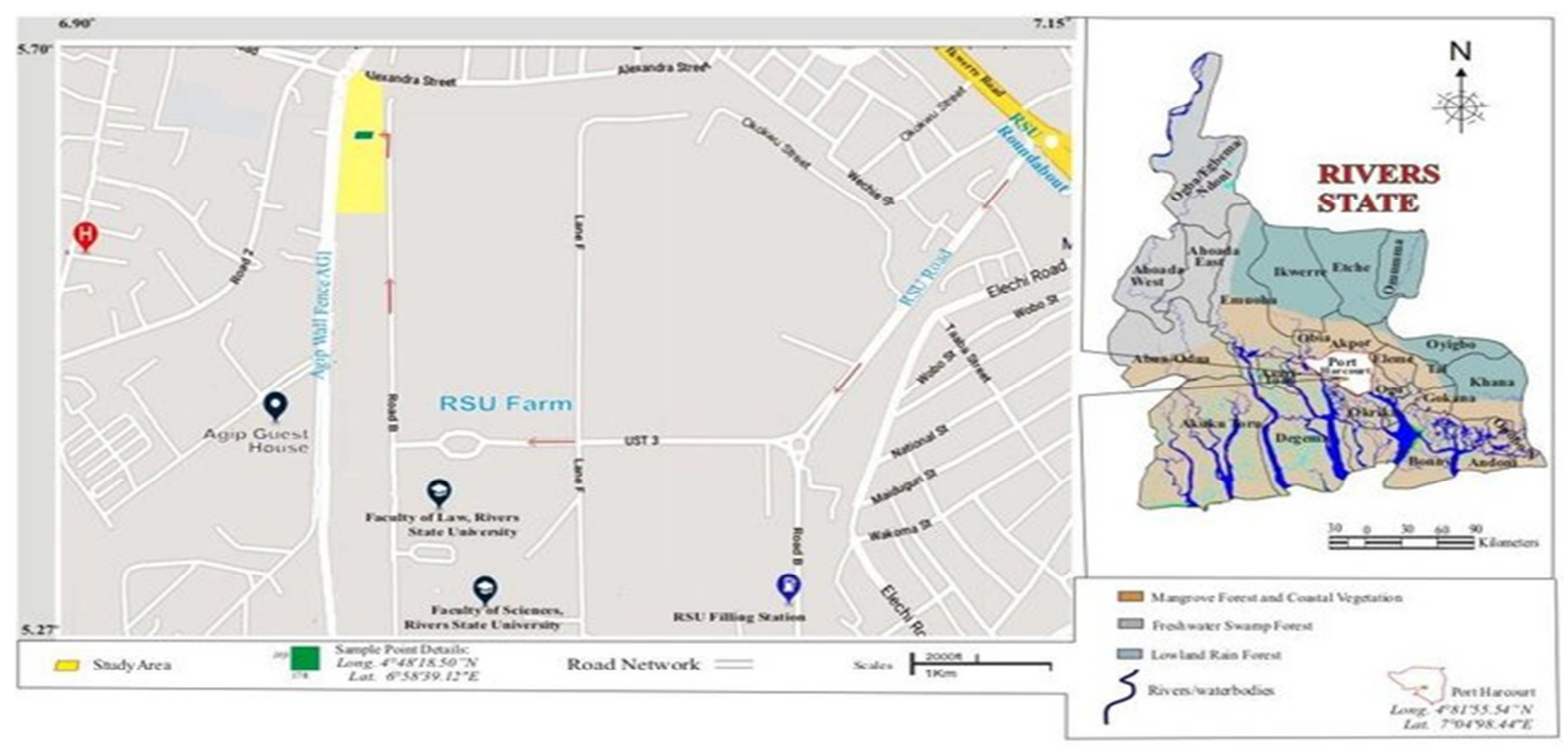

Source: [15].

Figure 1. Map of Experimental plots at RSU Farm. 


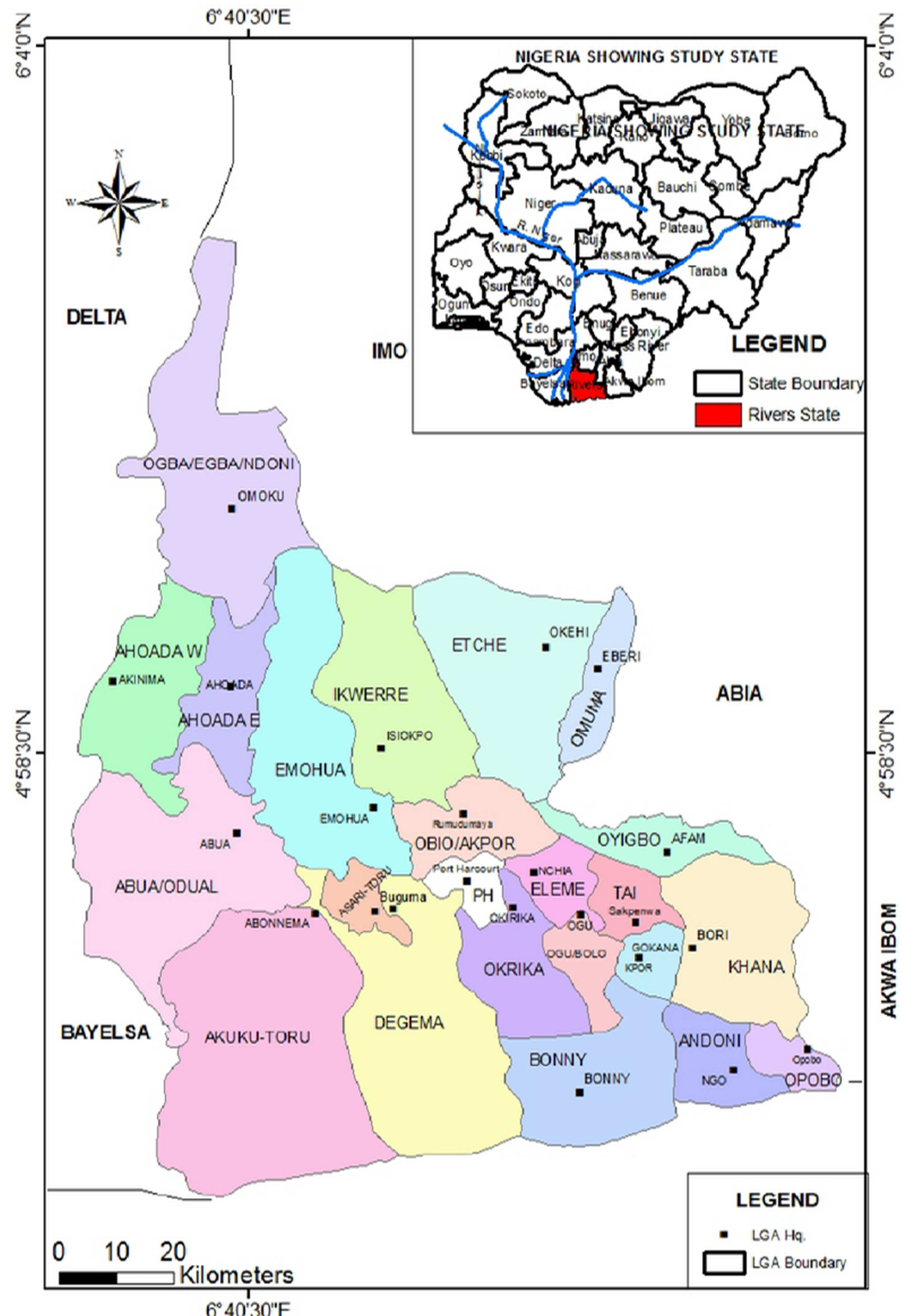

Source: [16].

Figure 2. Map of Rivers State showing the four local government areas of study. 


\section{Materials and Methods}

\subsection{Collection of Samples}

Cassava tubers were collected from four locations (Figures 1 and 2) in Rivers State: L1 (Rukpoku), L2 (Rivers State University agricultural farm (RSU farm)), L3 (Eleme community) and L4 (Nkpolu-Oroworukwo community).

\subsection{Heavy Metals Determination}

The Cassava tubers from the four locations were peeled, cut into small sizes, dried to remove the moisture and were then oven-dried to a constant weight using Galen Kamp oven at a temperature of $65^{\circ} \mathrm{C}$. These were pulverized to fine powder using a laboratory grinder. Samples ( $3 \mathrm{~g}$ each) were weighed into clean platinum crucibles and ashed at 450 $500^{\circ} \mathrm{C}$; then cooled to room temperature in a desiccator. Each resulting ash was dissolved in $5 \mathrm{ml}$ of $20 \%$ hydrochloric acid. The mixture was carefully transferred into a $100 \mathrm{ml}$ volumetric flask, distilled water added to make up the mark and agitated to mix properly. The resulting solutions were then analyzed for presence and concentrations of $\mathrm{Zn}, \mathrm{Fe}, \mathrm{Pb}$, $\mathrm{Cu}$ and $\mathrm{Mn}$ using atomic absorption spectroscopy (AAS).

\subsection{Determination of Hydrocarbons}

\subsubsection{Extraction Procedure}

Texas Natural Resource Conversion Commission method was adopted for extraction [17]. Each pulverized sample (2 g) was weighed into a clean extraction container. Dichloromethane $(10 \mathrm{ml})$ was added and mixed thoroughly and then allowed to settle. The mixture was carefully filtered into a clean extraction bottle using filter paper fitted into a Buchner funnel. Each extract was concentrated to $2 \mathrm{ml}$ and then transferred for separation. Glass wool was placed at the bottom of a $10 \mathrm{~mm}$ x $250 \mathrm{~mm}$ chromatographic column. Slurry of $2 \mathrm{~g}$ activated silica in $10 \mathrm{ml}$ dichloromethane was prepared and placed into the chromatographic column and sodium sulphate added to the top of the column. The column was rinsed with additional $10 \mathrm{ml}$ of dichloromethane and preeluted with $20 \mathrm{ml}$ of dichloromethane. This was allowed to flow through the column for about 2 min until the liquid in the column was just above the sodium sulphate layer. Immediately, $1 \mathrm{ml}$ of the extracted sample was transferred into the column. The extraction bottle was rinsed with $1 \mathrm{ml}$ of dichloromethane and added to the column as well. The stop cock of the column was opened and $8 \mathrm{ml}$ of eluent collected with a $10 \mathrm{ml}$ graduated cylinder. Just prior to exposure of the sodium sulphate layer to air, dichloromethane was added to the column in 1-2 ml increments. The eluent was labeled aliphatic. This separation procedure was carried out separately for all the extracts.

\subsubsection{Gas Chromatography}

The concentrated aliphatic fractions were transferred into labeled vials with caps for gas chromatographic analysis. Concentrated samples $(1 \mathrm{ml}$ each) were separately injected by means of a hypodermic syringe through a septum into the column. Separation occurred as the vapour constituent partitioned between the gas and liquid phases. The components were automatically detected as it emerged from the column at a constant flow rate by the flame-ionization detector whose response is dependent upon the composition of the vapor.

\section{Results}

The results of this study reveal the presence of heavy metals $\mathrm{Zn}, \mathrm{Fe}, \mathrm{Cu}$, and $\mathrm{Mn}$ in all study samples analyzed (Table 1) and they were all above Nigeria's Federal Environmental Protection Agency (FEPA) permissible ranges. However, the trend for occurrence of heavy metals in the samples was in the order Eleme $>$ Nkpolu-Oroworukwo $>$ Rukpoku $>$ RSU farm. $\mathrm{Pb}$ was below $0.00 \mathrm{ppm}$ in all samples.

Hydrocarbon content (Table 2) of analyzed samples shows the presence of PAHs (anthracene, acenaphthene, phenanthrene, fluoranthene, pyrene, benz (a) anthracene, benz (b) fluoranthene, indeno (1,2,3-cd) pyrene and dibenz (a, h) anthracene) and TPH. BTEX was below $0.00 \mathrm{mg} / \mathrm{kg}$ in all analyzed samples. TPH concentrations in all samples were above FEPA permissible range. TPH was detected in all samples analyzed in the order Eleme $>$ Nkpolu-Oroworukwo $>$ Rukpoku > RSU farm.

Table 1. Heavy metal concentration of experimental composite samples.

\begin{tabular}{|c|c|c|c|c|c|}
\hline Heavy metals & L1 & $\mathbf{L 2}$ & L3 & L4 & FEPA Range \\
\hline $\mathrm{Zn}(\mathrm{ppm})$ & 0.287 & 0.285 & 0.297 & 0.290 & $0.015-0.020$ \\
\hline $\mathrm{Fe}(\mathrm{ppm})$ & 0.665 & 0.662 & 0.667 & 0.665 & $0.010-0.634$ \\
\hline $\mathrm{Pb}(\mathrm{ppm})$ & $<0.00$ & $<0.00$ & $<0.00$ & $<0.00$ & $0.000-0.0001$ \\
\hline Mn (ppm) & 0.080 & 0.079 & 0.082 & 0.080 & $0.002005-0.002009$ \\
\hline
\end{tabular}

L1=Rukpoku, L2=RSU farm), L3=Eleme community, L4=Nkpolu-Oroworukwo community.

Table 2. Hydrocarbon concentration of experimental composite samples.

\begin{tabular}{|c|c|c|c|c|c|}
\hline Hydrocarbons & L1 & L2 & L3 & L4 & FEPA Range \\
\hline PAH (mg/kg) & $1.10000 \mathrm{e}-2$ & $0.70000 \mathrm{e}-2$ & $1.10002 \mathrm{e}-2$ & $1.10001 \mathrm{e}-2$ & $1.200-1.201$ \\
\hline TPH (mg/kg) & 1.3501 & 1.3480 & 1.3609 & 1.3520 & $0.3000-0.1000$ \\
\hline BTEX $(\mathrm{mg} / \mathrm{kg})$ & $<0.00$ & $<0.00$ & $<0.00$ & $<0.00$ & 0.00 \\
\hline
\end{tabular}

L1=Rukpoku, L2=RSU farm), L3=Eleme community, L4=Nkpolu-Oroworukwo community. 


\section{Discussion}

$\mathrm{Zn}, \mathrm{Fe}, \mathrm{Pb}, \mathrm{Cu}$, and $\mathrm{Mn}$ in the cassava samples were determined using AAS. From the results obtained (Table 1), $\mathrm{Pb}$ was not detected in all experimental samples, $\mathrm{Fe}$ had the highest concentration in cassava from Eleme community, a gas flared area that hosts Eleme petrochemical company limited, and least in RSU farm sample. Zn was also high in Eleme community sample and least in RSU farm sample. This result agrees with the observation of other researchers [5], who reported that heavy metal concentration in cassava tubers and plantain fruits are higher in petroleum activities areas. $\mathrm{Cu}$ had a high value in Eleme community sample but low in the sample gotten from RSU. Manganese concentration in the samples had same trend as that of Fe and $\mathrm{Zn}$. The high concentrations of heavy metals in cassava tubers harvested from Eleme community may be attributed to activities of the oil and gas companies and other anthropogenic activities that release heavy metals into the environment, hence the uptake of the heavy metals in the crops grown on the polluted soil [18]. The low concentrations of heavy metals observed in RSU farm may be attributed to the location of the farm, having almost no anthropogenic activity in the area. Cassava tubers gotten from NkpoluOroworukwo community was also high in heavy metals content; this may be due to the high activity of motorists and automobile around the area, hence releasing heavy metals into the environment. This is in consonance with the previous reports [19], which infers the presence of heavy metals in soils around automobile activities. Rukpoku sample also recorded heavy metals concentrations.

The findings of this study on heavy metals agree with the study of previous studies [20], except for the concentration of $\mathrm{Pb}$. Their study revealed higher concentration of lead, with corresponding high level of iron, copper and zinc in various food crops harvested from areas of high industrial activities compared to crops from the non-industrialized areas. Gas flare activity and other anthropogenic activities [21] carried out in Eleme community may have contributed to the increased heavy metal accumulation in the cassava grown there.

Results obtained (Table 2) revealed that the concentration of polyaromatic hydrocarbons was higher in Eleme community sample than in the sample from RSU farm. Total petroleum hydrocarbon content in Eleme community sample was observed to be highest and least in RSU farm sample. Benzene, toluene, ethyl benzene, and xylene contents in all the samples were observed to be $\leq 0.00$ $\mathrm{mg} / \mathrm{kg}$. Food crops from areas exposed to gas flare are markedly contaminated by carcinogenic PAHs and may pose public health concerns [22]. High concentration of hydrocarbons in the experimental samples from Eleme community can be attributed to gas flaring and activities of the companies within the community while that of samples from Mile 3 may be attributed to anthropogenic activities [23]. TPH contents of the samples were in the order: Eleme community $>$ Mile $3>$ Rukpoku $>$ RSU farm. Cassava tubers harvested from areas with more industrial and anthropogenic activities were observed to have higher concentrations of heavy metals and hydrocarbons.

\section{Conclusion}

The findings of this study have shown that cassava cultivated in gas flared areas have high (above permissible limits) concentrations of zinc, iron, copper, manganese, total polycyclic hydrocarbon and polyaromatic hydrocarbons. To mitigate this health concern, adherence to laws that promote sustainable development and eco-friendly environment should be encouraged.

\section{Conflict of Interest}

The authors declare that they have no competing interest.

\section{Acknowledgements}

The authors acknowledge Mr. Graham Douglas Dawari for his assistance in the experimental procedures and bench work

\section{References}

[1] FAO/IFAD (2000). The World Cassava Economy: Facts, Trends and Outlooks, Food and Agriculture Organization of the United Nations and International Fund for agricultural Development. Rome.

[2] FAOSTAT (2010). Food and agricultural Commodities production. Food and Agricultural Organization of the United Nations Statistics Database.

[3] Odinga, T., Ayalogu, E. O. and Essien, E. B. (2016). Effect of Effluent from Port Harcourt Refining Company on Hepatic and Reproductive Functions of Wistar Albino Rats. Journal of Natural Sciences Research. 6 (4): 112-117.

[4] Odokuma, L. O. (2009). Effect of cultural Age and Biomass Concentration on Heavy Metal uptake by three Axenic Bacterial Cultures. Advances in Applied Science 3 (3): 339349 .

[5] Idodo-Umeh, E. W. G. and Ogbeibu, A. E. (2010). Bioaccumulation of heavy metals in cassava tubers and plantain fruits grown in soil impacted with petroleum and nonpetroleum activities. Research journal of Environmental Sciences. 4 (1): 33-41.

[6] Hong, A. H., Law, P., Ling, S. and Onni, S. (2014). Heavy metal concentration levels in soil at Lake Geriyo irrigation site, Yola, Adamawa state, North Eastern Nigeria. International journal of Environmental monitoring and analysis. 2 (2): 106111.

[7] Demirezen, D. and Ahmet, A. (2006). Heavy metal levels in vegetables in Turkey are within safe limits for $\mathrm{Cu}, \mathrm{Zn}, \mathrm{Ni}$ and exceeded for $\mathrm{Cd}$ and $\mathrm{Pb}$. Journal of food quality. 29: 252-265. 
[8] Nwaichi, E. O., Frac, M., Nwoha, P. A. and Eragbor, P. (2015). Enhanced phytoremediation of crude oil-polluted soil by four plant species: effect of inorganic and organic bioaugmentation. International Journal of Phytoremediation. 17 (12): 12531261.

[9] Ogali, R. E., Osuji, L. E. and Ayodele, O. (2007). Acute toxicity of the water soluble fraction of spent lubricating oil on the African catfish. Chemical Biodiversity 4: 2755-2765.

[10] Abdulazeez, T. L. and Peter, F. (2017). Polycyclic aromatic hydrocarbons. A. review, Cogent Environmental Science, 3: 1. DOI: $10.1080 / 23311843.2017 .1339841$.

[11] Nwaichi, E. O., Chuku, L. C. and Ighoavwogan, E. (2016). Polycyclic Aromatic Hydrocarbons and Selected Heavy Metals in Some Oil Polluted Sites in Delta State Nigeria. Journal of Environmental Protection. 7, 1389-1410.

[12] Odinga, T. B., Ayalogu, E. O. and Essien, E. B. (2015). Physicochemical and hydrocarbon content of effluent from port Harcourt refining company and its effect on renal function of albino rats. Journal Research in environmental Science and technology 4 (2): 028-031. DOI: http:/dx.doi.org/10.14303/jrest.2015.132.

[13] Bolden, A. (2015). Retrieved from https://fromthestyx.wordpress.com/2015/04/15/btex-exposureis-an-increasing-public-health-concern.

[14] Gibson, D. T. and Parales, R. (2000). Aromatic hydrocarbon dioxygenases in environmental biotechnology. Current Opinion in Biotechnology 11: 236-243.

[15] Ogbonna, D. N., Ekweozor, I. K. E., Nrior, R. R. and Ezinwo, F. E. (2019). Evaluation of Organic Nutrient Supplements and Bioaugmenting Microorganisms on Crude Oil Polluted Soils. Current Journal of Applied Science and Technology 38 (6): 119, DOI: 10.9734/CJAST/2019/v38i630395.
[16] Naluba, G. N. and Arokoyu, S. B. (2015). Evaluation of local government headquarters as regional development centers in Rivers state, Nigeria. International Journal of Scientific Research and Innovative Technology. 2 (11): 2313-3759.

[17] Texas Natural Resource Conservation Commission, TNRCC Method 1005, Total Petroleum Hydrocarbon, Revision 03, June 1, 2001.

[18] LeCoultre, D. (2001). A Meta-Analysis and risk assessment of heavy metal uptake in common garden vegetable, East Tennessee State University, USA.

[19] Aloysius, A. P., Rufus, S. and John, O. O. (2013). Evaluation of heavy metals in soils around auto mechanic workshop clusters in Gboko and Makurdi, Central Nigeria. Journal of Environmental Chemistry and Ecotoxicology, 5 (11): 298-306, DOI: 10.5897/JECE2013.0295.

[20] Hart, A. D., Oboh, C. A., Barrimalda, I. S. and Sokari, T. G. (2005). Concentration of trace metals (lead, iron, copper and zinc) in crops harvesting in some oil prospecting locations in River state Nigeria. Port-Harcourt. Afrika Linkpress.

[21] Mgbemena, N. M., Ilechukwu, I., Ubadi, J. O. and Ndukwe, G. I. (2017). Status of heavy metals pollution in the sediments of the new Calabar river in Rivers state, Nigeria. Journal of Chemical Society of Nigeria. 42 (2): 84-87.

[22] Nwaichi, E. O., Wegwu, M. O. and Nwosu, U. L. (2014). Distribution of selected carcinogenic hydrocarbon and heavy metals in an oil polluted agricultural zone. EMAS; 186 (12): 8607-8706.

[23] Ilechukwu, I., Osuji, L. C., Onyema, M. O. and Ndukwe, G. I. (2016). Occurrence and sources of aliphatic hydrocarbons in soils within the vicinity of hot mix asphalt plants in Obigbo and Igwuruta areas of Rivers State, Nigeria. Journal of Applied Sciences and Environmental Management. 20 (4): 1087-1094. http://dx.doi.org/10.4314/jasem.v20i4.24. 